\title{
REPRODUCTIVE AND BODY WEIGHT PERFORMANCE OF THE NEW ZEALAND WHITE RABBITS IN THE HUMID TROPICS OF NIGERIA.
}

\author{
I. K. ODUBOTE and J.O. AKINOKUN, \\ Department of Animal Science, Obafemi Awolowo University \\ Ile-Ife, Nigeria. \\ (Received 24 January 1990 , accepted 19 June 1991)
}

\begin{abstract}
Fifty two litters obtained over a period of 8 months (December 1986-July 1987) from the mating of eight bucks with twenty nine does (first mating) and twenty three does (second mating) all belonging to the New Zealand White breed of rabbits were used in this anaylysis. Mean gestation length, number of mating to conception, litter size at birth and parturition interval were $31.6 \pm 0.2$ days, $1.4 \pm 0.1,5.6 \pm 0.3$ pups and $79.0 \pm 4.5$ days respectively. Litter weight at birth, 3,6 and 8 weeks of age were $230.4 \pm 9.5 \mathrm{~g}, 602.1 \pm 35.6 \mathrm{~g}, 1247.5 \pm 81.5 \mathrm{~g}$ and $1673.0 \pm 112.3 \mathrm{~g}$ respectively. Parity significantly $(P<0.05)$ affected number of mating to conception and litter birth weight. Litter weight at all ages were influenced $(P<.01)$ by corresponding litter sizes at such ages. Sire neither had any effect on litter weight at all ages nor on any of the reproductive parameters studied. Litter size at birth was negatively correlation with gestation length $(-0.08)$, number of matings to conception $(-0.27)$ and average birth weight $(-0.42)$.
\end{abstract}

\section{INTRODUCTION}

The problems of inadeyuate supply of protein from the traditional livestock-cattle, sheep, goat and chickens has led to the intensification of efforts to improve on the productivity of these animals. Concurrent, with this approach was the search for other sources of animal protein and the rabbit has been thought of as being suitable in this ragard. The most advantageous attributes of rabbits are their high reproductive potential and fast growth rate (Lebas et al, 1986). This is as a result of their short gestation length, early sexual maturity, high prolificacy and ability to rebreed shortly after parturition, all leading to a short generation interval. However, there is a Nigeria Journal of Animal Production 18 (1991) paucity of information on base line performance level and correlation among traits of economic importance for our environment.

The objectives of the study were therefore to evaluate both the reproductive and the body weight performance of the New Zealand White rabbit in the humid tropics.

\section{MATERIALS AND METHODS}

The experiment was conducted in the Rabbitry Unit of the Obafemi Awolowo University Teaching and Research Farm, Ile-Ife, Nigeria between December 1986 and July 1987. A total of twenty nine white does were randomly allocated and mated to eight New Zealand White bucks to obtain two litters each except for six does that died during the study. A total of fifty-two litters which was made up of 290 pups were thus obtained.

The ages of the rabbits ranged from six to eight months for the does (all primiparous) while the bucks were over a year old. Inbreeding was avoided in the rabbitry unit. The weight of the does at the commencement of the experiment was between $1.5 \mathrm{~kg}$ and $1.8 \mathrm{~kg}$. The average minimum and maximum temperatures over the period of study were, respectively $22.2 \pm 0.7^{0} \mathrm{c}$ while the mean relative humidity in the morning and afternoon were $78.9 \%$ and $53.1 \%$.

The rabbits were housed individually in row cages made of galvanized expanded metal measuring $75 \mathrm{~cm} \times 60 \mathrm{~cm} \times 45 \mathrm{~cm}$ and raised to a minimum height of $1 \mathrm{~m}$. The galvanized expanded metal cage was further covered with poultry wire mesh. Each cubicle was provided with feed and water clay pots. The rabbits were tatooed and identification tags were hung on the frontal side of the cages. The rabbits were fed commercially compounded pellets. Proximate analysis of the feed showed that it contained 
$13.8 \%$ protein and a gross energy of $3.86 \mathrm{kcal} / \mathrm{kg}$ of feed. Quantity of feed supplied was $100-150 \mathrm{~g}$ daily and this was later increased to between 150 and $250 \mathrm{~g}$ during pregnancy or lactation. The feed was supplemented with Panicum maximum.

Mating was carried out in the morning by taking the doe to the buck assigned to it. If mating occured this was recorded and on the 14th day post coitum the bred doe was palpated for presence of fetuses. Non pregnant does were immediately put up for mating until conception occured. On the 28 th or 29 th day post coitum, open top wooden kindling boxes, with holes drilled at the bottom, were placed with the expectant doe inside the cage. The litters were inspected.on being delivered for any dead at birth of dead in utero by means of the lung floatation test. Four weeks post partum, the fryers were weaned and removed to new cages at 6 weeks of age.

Records on number of matings to conception gestation length and litter size at bith were kept. Also individual body weight records at birth, 3, 6 and 8 weeks were also recorded.

\section{Statistical analysis}

Means and standard errors for gestation length number of mating to conception, litter size at birth, parturition interval, individual body weight and litter weight at birth, 3, 6 and 8 weeks were computed. Correlation coefficients (Pearson's) were calculated for some of the traits. Significant differences between means were determined using the Duncan's New Multiple Range Test (Steel and Torrie, 1980).

The statistical models used for the analysis of body weights at the all ages and traits of reproductive performance were

$Y_{i j k l}=\mu+S_{i}+D_{i j} P k+E_{i j k l}$ and

$Y_{i j k}=\mu+S_{i}+P_{j}+E_{i j k}$, respectively

where $Y_{i j k l}=$ Observation on the $i^{\text {th }}$ animal belonging to the $k^{\text {th }}$ parity delivered by the $j^{\text {th }}$ dam mated to the $\mathrm{i}^{\text {th }}$ sire.

$Y_{i j k}=$ Observation on the $k^{\text {th }}$ animal belonging to the $\mathrm{j}^{\text {th }}$ parity produced by the $\mathrm{i}^{\text {th }}$ sire.

$\mu=$ Overall mean

$S_{i}=$ effect of the $i^{\text {th }}$ sire ( $i=1$ to 8$)$

$D_{i j}=$ effect of the $j^{\text {th }}$ dam mated to the $i^{\text {th }}$ sire (j = 1 to 29)

$\mathbf{P}_{\mathbf{k}}=$ effect of the $\mathbf{k}^{\text {th }}$ parity $(k=1,2)$

$P_{j}=$ effect of the $j^{\text {th }}$ parity $(j=1,2)$

$E_{i j k l}$ and $E_{i j k}=$ random error associated with

$Y_{\mathrm{ijkl}}$ and $Y_{\mathrm{ijk}}$ respectively.

\section{RESULTS}

\section{Reproductive Peformance:}

The mean gescation length, number of matings to conception, litter size at birth and parturition interval are as shown in Table 1. Gestation length ranged from 27 to 34 days while the number of matings to conception varied between 1 and 5 . Conception rate was $71 \%$. Litter size at birth and parturition interval varied from 2 to 9 and 58 days to 101 days respectively. Table 2 shows the effect of parity on number of matings to conception and litter size at birth. Correlation coefficient of $-0.08(P>0.05)$ was obtained when litter size at birth was correlated withgestation lengh , and $-0.27(P<.01)$ when it was correlated with number of matings to cenception.

\section{Body Weight:}

The mean body weight and litter weight at all ages studied are as shown in Table 3. Body weight at birth, 3, 6 and 8 weeks ranged from 21 to $60.5 \mathrm{~g}, 77$ to $263 \mathrm{~g}, 176.5$ to $543 \mathrm{~g}$ and 271 to $808.5 \mathrm{~g}$ respectively. Litter weight at birth, 3,6 , and 8 weeks also ranged from 58 to $358 \mathrm{~g}, 166.5$ to $991 \mathrm{~g}, 367.5$ to $2163.5 \mathrm{~g}$ and 648 to 2494 respectively. There was no significant $(P>0.05)$ parity effect on body weights and litter weights at all

TABLE 1: MEANS AND STANDARD ERROR OF REPRODUCTIVE TRAITS IN DOMESTIC RABBITS.

\begin{tabular}{llll}
\multicolumn{1}{c}{ Traits } & N & Mcan & S.E. \\
\hline Gestation length & 52 & 31.6 days & 0.2 \\
$\begin{array}{l}\text { Number of matings } \\
\text { to conception }\end{array}$ & 71 & 1.4 & 0.1 \\
Litter sizc at birth & 52 & 5.6 & 0.3 \\
Parturition interval & 23 & 79.0 doys & 4.5 \\
\end{tabular}

N refers to sample size

S.E. = Standard error of the mean. 
TABLE 2: EFFECT OF PARITY ON NUMBER OF MATINGS TO CONCEPTION AND LITTER SIZE AT BIRTH.

\begin{tabular}{cc}
\hline Traits & 1st Litter 2nd Litter \\
\hline $\begin{array}{c}\text { Number of mating } \\
\text { conception }\end{array}$ & $1.6 \pm 0.2 \mathrm{a}(46) 1.1 \pm 0.1 \mathrm{~b}(25)$ \\
Litter size at birth & $5.2 \pm 0.3(25) 6.1 \pm 0.3(23)$
\end{tabular}

Figures in parentheses refer to sample size

$a, b=$ Means along the same row with different superscripts were significantly different $(\mathrm{P}<.05)$.

ages except for litter birth weight $(P<0.05)$, (Table 4). The effect of sire on litter weight at all ages was not significant $(P>.05)$. Litter size, however, significantly $(\mathrm{P}<.05)$ influenced litter weight at all ages (Table 5).

TABLE 3: MEANS AND STANDARD ERROR OF BODY WEIGH'IS OF DOMESTIC RABBITSS AT VARIOUS AGES(G)

\begin{tabular}{lccc}
\hline \multicolumn{1}{c}{ Traits } & $\mathrm{N}$ & Mean & S.E. \\
& & & \\
\hline Birth weight & 290 & 42.9 & 0.5 \\
3 wk body weight & 175 & 151.2 & 2.9 \\
6 wk body weight & 149 & 360.6 & 6.8 \\
8 wk body weight & 138 & 510.5 & 9.6 \\
Litter birth weight & 52 & 230.4 & 9.5 \\
3 wk litter weight & 42 & 602.5 & 35.6 \\
6 wk litter weight & 42 & 1247.5 & 81.5 \\
8 wk litter weight & 41 & 1673.0 & 112.3 \\
\end{tabular}

$\mathrm{N}$ refers to the sample size

S. E. = Standard error of the mean

\section{DISCUSSION}

All the does used in the study were bred even during the period of high ambient temperature confirming the observation of Somade (1982) that if mating is attempted often enough, does can be successfully mated even during the hot dry season. Average number of matings to achieve
TABLE 4: EFFECT OF PARITY ON LITTER WEIGHT AND AVERAGE BODY WEIGHT OF DOMESTIC RABBITS AT VARIOUS AGES.

\begin{tabular}{cll}
\hline Traits & 1st Litter (g) & 2nd Litter (g) \\
\hline Litterbirth weight & $208.2 \pm 13.0^{a}(29)$ & $258.4 \pm 11.5^{\circ}(23)$ \\
3 wk litter weight & $585.0 \pm 38.8(19)$ & $617.8 \pm 30.5(23)$ \\
6 wk litter weight & $1142.9 \pm 103.9(19)$ & $1352.0 \pm 69.5(23)$ \\
8 wk litter weight & $1545.8 \pm 157.6(18)$ & $1800.3 \pm 92.2(23)$
\end{tabular}

Figures in parentheses refer to sample size

a, $b$ - means along the same row with different superscript were significantly different $(\mathbf{P}<.05)$

conception, 1.40 , compares favourably with 1.39 and 1.49 obtained by Novy (1974) and Patridge et al. (1981) respectively.

Litter size at birth obtained in this study was lower than 7.4 repoted by Lukefahr and Goldman (1985) in Cameroon. This difference may be attributed to the size (body weight) of the doe as they bred does that were $2.5 \mathrm{~kg}$ and above. Afifi et al. (1989) reported that the weight of the doe affects the litter size at birth. Another reason may be the poor quality of feed offered. The non-significance of sire effect on litter size at birth and number of matings to conception agreed with observation of Patridge $e t$ al.,(1981).

Parturition interval obtained in this study exceeds those reported in literature. With a four week post partum mating, a theoretical parturition interval of 58 days is expected but this was extended by 21 days. The long parturition interval was as result of the failure of the does to mate and conceive readily. The matings were conducted in the dry season which had been noted to reduce conception rate thus prolonging the mating period and hence the parturition interval. Secondly, the poor quality of the feed may not be adequate for the doe during pregnancy and lactation. Some of the does were not in good condition prior to the second mating. Omole (1982) had concluded that a feed containing $14 \%$ crude protein is inadequate to support reproduction.

The body weights reported agree with the reports of Ekpenyong (1984) and Somade and Adesina (1990). The authors agreed that the 
TABLE 5: EFFECT OF LITTER SIZE ON LITTER WEIGHT OF DOMESTIC RABBITS AT VARIOUS AGES $( \pm$ S.E.)

\begin{tabular}{|c|c|c|c|c|c|c|c|c|c|}
\hline \multirow[b]{2}{*}{ Trait } & \multirow[b]{2}{*}{1} & \multicolumn{8}{|c|}{ Litter Size } \\
\hline & & 2 & 3 & 4 & 5 & 6 & 7 & 8 & 9 \\
\hline Litter birth weight & NA & $\begin{array}{l}82.8 \\
\pm 24.8^{a} \\
(2)\end{array}$ & $\begin{array}{l}130.3 \\
\pm 12.2^{b} \\
(5)\end{array}$ & $\begin{array}{l}198.4 \\
\pm 8 .^{b c} \\
(5)\end{array}$ & $\begin{array}{l}224.7 \\
\pm 10.2^{c} \\
(14)\end{array}$ & $\begin{array}{l}240.5 \\
\pm 14.5^{\mathrm{cd}} \\
(12)\end{array}$ & $\begin{array}{l}275.8 \\
\pm 22^{\text {cde }} \\
(6)\end{array}$ & $\begin{array}{l}8295.6 \\
\pm 18.0^{\mathrm{d} \varepsilon} \\
(5)\end{array}$ & $\begin{array}{c}9336.5 \\
\pm 10.8^{\mathrm{e}} \\
\quad(3)\end{array}$ \\
\hline 3 wks litter weight $(\mathrm{g})$ & $\begin{array}{l}166.5 \\
\pm 0.0^{\mathrm{a}} \\
(1)\end{array}$ & $\begin{array}{l}317.5 \\
\pm 0.0^{b} \\
(1)\end{array}$ & $\begin{array}{l}527.4 \\
\pm 20.5^{c} \\
(14)\end{array}$ & $\begin{array}{l}597.9 \\
\pm 42.08^{c} \\
(8)\end{array}$ & $\begin{array}{l}688.9 \\
\pm 41.8^{\mathrm{cd}} \\
(12)\end{array}$ & $\begin{array}{l}811 \\
\pm 33.5^{\mathrm{d}} \\
(3)\end{array}$ & $\begin{array}{l}682 \\
\pm 6.7^{\mathrm{cd}} \\
(3)\end{array}$ & & \\
\hline 6 wks litter weight (g) & $\begin{array}{l}500 \\
\pm 0.0^{\mathrm{a}} \\
(1)\end{array}$ & $\begin{array}{l}791.4 \\
\pm 89.0^{\mathrm{ab}} \\
(6)\end{array}$ & $\begin{array}{l}1080.3 \\
\pm 62.2 \\
(14)\end{array}$ & $\begin{array}{l}1437.3 \\
\pm 59.5^{b c} \\
(14)\end{array}$ & $\begin{array}{l}1706.5 \\
\pm 161.6^{c} \\
(4)\end{array}$ & $\begin{array}{l}1763.7 \\
\pm 207.7^{\mathcal{C}} \\
(2)\end{array}$ & & & \\
\hline 8 wks litter weight (g) & $\begin{array}{l}648 \\
\pm 0.0^{\mathrm{a}}\end{array}$ & $\begin{array}{l}1032.7 \\
\pm 61.8^{a b}\end{array}$ & $\begin{array}{l}1608 \\
\pm 82.8^{b c}\end{array}$ & $\begin{array}{l}2055.3 \\
\pm 96.0^{c}\end{array}$ & $\begin{array}{l}2265.4 \pm \\
199.5^{\mathrm{cd}}\end{array}$ & $\begin{array}{l}2393.5 \\
\pm 79.5^{\mathrm{d}}\end{array}$ & & & \\
\hline
\end{tabular}

Figures in parentheses refer to the number of records used to calculate the means.

$a, b, c, d, e$, Means along the same row with different superscript were significantly different $(P<.05)$

NA- There was no litter comprising one kid.

S.E. - Standard error of the mean.

body weights were lower than the values reported in the literature for the rabbits raised in temperate environments. Owen (1976) has observed that high ambient temperatures and the low relative humidity reduced feed intake and consequently result in low body weight gain. Somade and Adesina (1990) further suggested differences in nutrition and general management of rabbits in the two environments as plausible reasons.

The significant effect of litter size on litter weight is similar to the reports of Afifi $e t$ al., (1980) and Lukefahr et al.,(1983). Therefore selection for improvement in litter size at birth is likely to result in increased litter weight. However, the breeder has to contend with lower average body weight. The non significant parity effect on litter weight at all ages except at birth may be due to the fact that factors other than uterine environment become more important and these may include feeding, milk production and high ambient temperature.
The high variability expressed for body weights at the various ages suggests a wide genetic -esource yet untapped. Appreciable improvement in body weight of the rabbits could thus be achieved through selection programmc after improvement in environmental conditions has been satisfied.

\section{REFERENCES}

AFIFI, E. A., (;ALAL, E.S.E., EL-()KSHI, H. A. and KADRY, A. E. (19)(0). Intcrrelationships among doe's weight, litter weight and body weight at different ages in rabhits. Esypl J. Anim. Prod. 20(2): 127. 1.3.

AFIFI, E.A., KHALIL, M.H.and I:MARA, M.E. (1989). Effects of maternal performance and litter preweaning traits in doc rabhits. J. Anim. Breed. (ient. 1(k):358-34,2. 
EKPENYONG, A.S (1984). Comparative growh of rabbits fed different levels of browsc plants. J. Appl. Rabbil Res. 7:144 145.

LEBAS. F, COUDERT, P. ROUVIER, R. and H. de ROCHAMBEAU (1986). The rabbits: husbandry, health and production. FAO Animal Production and Health Series No 21.Rome 235p.

\section{LUKEFAHR, S., HOHENBOKEN, W.D.,} CHEEKE, P.R. and PATTON, N.M. (1983). Characterisation of straightbred and crossbred rabbits for milk production and association to market rabbit. J. Ainm. Sci. 57(5): 1100-1107.

LUKEFAHR, S. and GOLDMAN, M. (1985). A technical assessment of production and economic aspects of small scale rabbit farming in Cameroon.J. Appl. Rabbit Res. 8:126135.

NOVY, J. (1974). Variation and genetic determination of fertility in different rabbit breeds. Acta Zoo. Nitra 25: 179-191.
OMOLE, TA. (1982). Efiect of level of protein on growh and reproductive performance. J. Appl. Rabbit Res. 5:83.

OWEN, J. E. (1976). Rabbit production in tropical developing countries: a review. Thop. Sci. 18: (4): 203-210.

PATRIDGE, G.G., FOLEY, S. and CORRIGALL, W. (1981). Reproductive performance in purebred and crossbred commercial rabbits. Anim. Pro. 32: 325-331.

SOMADE, B. (1982). Influence of two environments on the reproductive performance of New Zealand White rabbits J. Anim. Prod. Res. 1982 (2): 113-122.

SOMADE, B. and ADESINA, A. (1990). Influence of the breed of doe and season on the growth rate of rabbits. Beitr. trop, Landwirtsch. Vet. Med. 28. L.2: 175-183.

STEEL, R.G.D and TORRIE, J.H. (1980). Principles and procedures of statistics. 2nd ed. McGraw Hill. London. 633p. 